\title{
In-Service LTE Program for Chinese Private Institute English Teachers
}

\author{
Xiaojing Zhang* \\ New Oriental Wuhan School, Wuhan 430015, Hubei Province, China \\ *Corresponding author: Xiaojing Zhang, zhangxiaojingxdf@163.com
}

\begin{abstract}
This paper describes a half-year in-service Language Teacher Education (LTE) program, targeting the trainee teachers who work in Chinese private English institutes. This is to better prepare them at the outset of their career. Primarily intending to build the trainee teachers' professionalism and raise their awareness, an overall illustration of adopted training courses and choice of activities are introduced in this paper. Focusing on integrating instructional knowledge from ESL and English language teaching, the LTE program schedule will allow majority of readers to implement during their daily teaching and research activities. Principles underpinning this program design are illustrated one by one. A course like this may not foster all teachers to become professionals at once, but to be a reflective practitioner can be a reachable goal, as accumulation of professional expertise is based on teachers' capability of understanding how to reflect on teaching.
\end{abstract}

Keywords: Language teacher education; Trainee teacher; Training; LTE program; Reflective practitioner

Publication date: August 2021; Online publication: August 30, 2021

\section{Introduction}

This paper describes a long-term in-service language teacher education (LTE) program, for trainee teachers who work in private English institutes in China. For trainee teachers who have just stepped into the society, a systematic LTE program could help them a lot in adapting to the high-paced development of institutes and in keeping abreast with the neoliberal trend of educational market. Thus, this program lasts for a halfyear time, supporting them at the beginning of their career, primarily intending to build their professionalism and raise their awareness, so they are able to educate learners of all ages and deal with the 'customers' (i.e., learners and learners' parents) more effectively and confidently (Bolam, 1986).

In this paper, the author will first present the context of teachers working in private institutes in China. Then comes the rationale for the choice of activities targeting trainee English teachers in such institutes as well as the relevant principles underpinning this LTE program. At last, an overall illustration of the course adopted is being analyzed, which respectively goes to a first introduction of its schedule, process and then the evidence of how the content of this course reflects all principles.

\section{Context}

Due to the trend of globalization, more information exchange appears between countries in a wide range of realms. One consequence of this phenomenon is that the cultural quality of people in developing countries has been gradually improving. Nowadays, acquiring an international language, such as English, has become a necessity for young people not to lag behind others. Therefore, an increasing number of students would like to take English Proficiency Test (EPT) or study abroad to strengthen their competitiveness, resulting in more and more providers of private educational service emerging in the past decade.

The thriving private educational industry seems to bless English teachers with more opportunities to 
have a decent job. Unluckily, the fierce competition among these English institutes, on the other side, could also inflict heavy pressure on the teachers, because the job of being a competitive language teacher will become more demanding in private educational sectors. In other words, unlike English teachers in public schools, owing an advanced degree is no more the unique prerequisite for the teachers to sustain a stable career while working in private institutes. Other than the requirement on teachers' education background, the teachers' capability in attracting more customers, offering more considerate teaching service and fostering more high-score students counts more for the entrepreneurs of private educational companies in contemporary society. Like what is argued by Dewey $(1933,1938)$, teachers are responsible for all facets of their teaching and teaching consequences. He maintains the essential qualities that teachers shall be equipped with are being responsible and wholehearted.

Nonetheless, committing oneself into teaching in this way can be very daunting for teachers, especially in the institutes that have not recognized the broad responsibilities for their teachers. Then massive language teachers have to be reflective practitioners on their own, in case they fail to cater for their institutes' requirement, which is indeed a tough work to deal with.

Given the above context, it is undeniable that tremendous impact has been exerted on Chinese private institutes as well as their teachers, resulting from the demand of a highly-developing economic world. Teachers in private English institutes are obliged more duties of not only educating students in class, but also 'servicing' customers after class, such as communicating with the parents about each student's academic performance and unconditionally solving each student's questions in their own spare time, for the sake of their institute's 'prosperity'. Nonetheless, it is of little possibility for them to cultivate their comprehensive quality under such a tight working schedule, if no systematic teacher education is provided for their guidance.

\section{Rationale}

In the field of teaching English to speakers of other languages (TESOL), the knowledge base of a language teacher education program shall respond to a simple question: "Who teaches what to whom, where ${ }^{[5]}$." Specifically, Freeman and Johnson points out the LTE program should help teachers figure out the answers to the nature of the teacher-learner, the nature of schools and schooling, and the nature of language learning.

At the first place, in defining knowledge base in language teacher education, we must recognize that it is concerned with language teachers as the learners of language teaching instead of language itself ${ }^{[5]}$. A distinguish between "content" (i.e., teachers' perceptions of what shall be taught in a course) and "subject matter" (i.e., disciplinary perception) is needed. It is primary for language teachers to understand the complexity of learning classroom language teaching, by acknowledging existing practices and figuring out the way in which these practices happen ${ }^{[5]}$. Therefore, teaching practice seems to play a more central role in a LTE course ${ }^{[6]}$.

In addition, Allwright and Bailey (1991) demonstrates that language learning is a rather complicated process for students who learn from various sources, among which, the language teachers are one important element. However, few people are aware that teachers are actually individuals who keep thinking and learning all the time, rather than simple conduits of teaching knowledge to their students. Their cognition directly guides their teaching behavior. Thus, focus shall also be on the teacher-learner during the language teacher education (Kennedy, 1991). In the perspective of Freeman and Johnson ${ }^{[5]}$, the reconceptualized knowledge base of LTE program has to account for how language teachers learn to teach and the complex factors that contribute to their learning process. To be specific, aspects like language teachers' prior belief of how to teach language (e.g., Lortie, 1975; Johnson, 1994; Bailey, et al., 1996) and how their belief evolves throughout their careers (e.g., Genburg, 1992; Berliner, 1986) shall be considered in designing activities in the LTE program. Fundamental to such work, on the other hand, is to raise teachers' awareness 
of the context in which their teaching takes place.

An understanding of the context for teaching learning is of high priority in establishing effective knowledge base for language teacher education ${ }^{[5]}$. In teacher education, we consider schools as the places where teacher-learner conduct their teaching practice. As Freeman and Johnson ${ }^{[5]}$ says, teachers testify theory in practical and are socialized in their first year of work in school, which is a power place that creates and sustains values (e.g., Sizer, 1983; Lightfoot, 1983). The "hidden curriculum" (Denscombe, 1982) (i.e., values emphasized by the school) is a primary influence on what the teachers would supposed to be normal and usual in their classrooms.

Briefly speaking, in order to help the trainee English teachers to keep abreast with the demands of private educational sectors, the in-service education and training (INSET) program designed in this paper, for cultivating teachers as reflective practitioners, is based on the following principles, according to the knowledge base of language teacher education mentioned above.

(1) Offer channels for teaching practice knowledge learning

(2) Allow language teachers to express their thoughts

(3) Encourage teachers to carry out effective self-reflection

(4) Overcome isolated teacher development with collaborative endeavors

(5) Help trainee teachers understand more about the context they work in

The next section will further illustrate how these principles underpin the LTE program design.

\section{The course}

\subsection{Course schedule}

The course of LTE program consists of 24 sessions in total, all of which will be held on Tuesdays in successive 24 weeks within half-a-year time, so as to continuously support a group of trainee teachers at the first half year of their career. Since the in-service language teachers' busy schedule and their overwhelming workload after class leaves not much spare time for them, a more intensive education course is barely feasible, and may also undermine the private institute's normal schedule to operate. Besides, the weekends, as the days off for the students as well as teachers from public schools, turn into the precious time for some young people to make efforts on their English proficiency tests, by taking extra tutoring in private English institutes. Therefore, weekends become the busiest working time for teachers in private sectors, and it is better for the teacher educator to choose one day during the week to carry out the LTE program. On each Tuesday, the trainee teachers can have a whole-day time to look back on their teaching performance in the past week, to reflect on something old and to learn something new. As Moon and Lopez (1997) suggests, a course in LTE program needs to offer opportunities for language teachers to 'move back and forth' between their classroom and more instructive workshop.

Among all the sessions (i.e., 24 sessions), every three constitute one round (see Appendix 1), so there will be eight rounds in a LTE program. In each round, the first and second session (see Appendix 1 Session $1 \& 2$ ) focus on the learning and reflection of practical teaching skills, based on four language skills teaching (i.e. reading $\&$ writing in the first session and listening $\&$ speaking in the second), while the third one (i.e. see Appendix 1 Session 3) is intended to inform trainee teachers with more teaching resource input in the morning, and to offer time as well as channels for them to narrate problems they've encountered during daily work in the afternoon. Like what Duff and Uchida (1997) has said, teacher knowledge can be only grasped and reconstructed when pedagogical issues emerge during teaching. Thus, between each round of the course, the trainee teachers are asked to write down at least one problem puzzling them on a reflective journal, which conduces to form their habit of being a reflective practitioner. 


\subsection{Course process}

A world-wide survey of teacher education conducted by Darling-Hammond and Lieberman (2012) shows that successful programs are the ones that enable teachers to learn from each other, which is particularly true considering the situation of non-native English speaker teachers (NNESTs) ${ }^{[8]}$. As shown in Appendix 1, the first activity of session 1 and session 2 in each round is a video observation of senior teachers giving English lessons in classroom, a short but selected recording. As Glaser and Strauss (1967) has claimed, in a "grounded" category of knowledge base needed in the LTE program, the analysis of language teaching shall start with activities practiced in classrooms, as grounded in teaching phenomenon itself.

Subsequently, a discussion among groups of trainee teachers follows, leaving time for them to understand why these practices happen as the senior teachers do and link it to their previous experiential knowledge. Then comes their own demo class of the same subject theme, for the purpose of receiving feedback from other teachers. Indeed, only through teaching foreign language learners as well as receiving feedback can the student teachers apply knowledge and skills learned elsewhere (Richards and Nunan, 1990). Though the trainee teacher audiences are not foreign language students, they are actually counted as "foreign language learners." especially those who teach a different subject from the addresser in the demo class and have little knowledge about the pedagogy of the subject. What is more, these "foreign language learners" are open to share their sincere suggestions with another trainee teacher in that they are equal in their agency to some extent, and the feedback they provide is what a language student in real classrooms cannot. That is the reason why teachers who teach different but related language skills (i.e. reading and writing; listening and speaking) are allocated together to attend the workshop on the same day (see Appendix 1 Session 1\&2).

In the afternoon of the session 1 and session 2, an one-hour self-reflection activity, accompanied with the opportunity to exchange with senior teachers, is designed in the LTE program. As mentioned above in the Context section, busy schedule and overwhelming workload do impede trainee teachers' endeavor to reflect on their teaching performance in daily life. The prevailing phenomenon is, even if language teachers, during the class, have found out some language point in their teaching materials need to be adapted or supplemented, they usually forget to update that after class, due to other teaching tasks waiting for them to deal with. This tendency will definitely exert a negative impact on teachers' professionalism, as differentiated needs of their learners have not been fulfilled in time. As a result, the goal of fostering increasing numbers of high-score students for their institute could become a reach less one. Luckily, this one-hour Self-reflection and Modification activity (see Appendix 1 Session 1\&2: Afternoon Session) blesses trainee teachers with the academic support and time to focus more attention on adapting the language points in teaching materials as well as their teaching performance. At last, the first two sessions finish with a second teaching practice of the trainee teachers, driving all of them, even some who insist their pedagogy as a perfect one, to make adaptation under the supervision of program trainer and the guidance from senior language teachers.

The process of the third session (see Appendix 1 Session 3) begins with two lectures given on different themes, in the morning. With eight rounds included in the whole LTE program (each round consists of three sessions as mentioned before), there are 16 lectures in total, all delivered by professional lecturers in order to raise teachers' awareness not only in devoting themselves to being professionals in teaching, but also in issues concerning other crucial realms despite the pedagogy learning, such as proper classroom discourse, establishing confidence as well as teaching style for oneself, how the private educational institute operates and its demands towards the teachers (see Appendix 2 Lecture Topic). All these issues are the ones that trainee teachers are unfamiliar with but need to know at the outset of their career. And it is better to inform the teachers working in private educational sectors in this way, for they have little time or energy to do extra reading after training. 
In the afternoon of session 3, teachers narrate the problems they encountered during work and discuss the problem-solving solutions with their colleagues. As NNESTs, they are more likely to experience the feelings of anxiety, which are attributed to reasons such as psychological, linguistic and sociocultural factors ${ }^{[14-15]}$. In coping with the related problems, a scope of issues that teachers are usually confronted with can be listed as prompts for them to reflect on in daily work: teacher identity, influence of prior learning experience, students of diverse language proficiency levels, proper interaction with students' parents and so forth.

Such a process of activities will be recursive in each round (i.e. three sessions) during the whole LTE program. A detailed illustration of the course content will be presented in the next section, based on the evidence of principles underpinning the course.

\subsection{Course content}

\subsubsection{Offer channels for teaching practice knowledge learning}

In terms of approaches to the teacher education, a distinction between action-system knowledge and subject-matter knowledge shall be made. Besides the trainee teachers' high language proficiency in teaching the subject content, action-system knowledge is what they are in lack of, which deals with teaching in general. As Day (1990) points out, one way for student teachers to acquire the action-system knowledge is to begin with focused observation of experienced language teachers. However, it is easy for an untrained observer to be overwhelmed by the complexity of what is going on, thus being unable to focus on crucial events if they are exposed in a real classroom (Day, 1990). Therefore, a limited and selected video recording lasting ten minutes is played for the trainee teachers, as a demo class observation activity at the beginning. Being access to a program of observation benefits the student teachers in many ways, such as raising their awareness of decision making and the principles underlying effective teaching, figuring out what is more effective classroom practices, and identifying practices as well as techniques to which the teacher-learner can apply in their own teaching (Day, 1990). This perspective has also been agreed upon by Gebhard, Gaitan and Oprandy (1990), who clarify the advantages of teacher-learners participating in observation program as granting them different views as well as fresh ideas about how to teach in classrooms. As for a selected video observation of classroom teaching, Day (1990) emphasizes, it can help the student teachers pay attention to particular teaching behaviors, allowing them to better evaluate effectiveness of such behaviors.

Granted, some researchers insist that observable behavior is the only reliable foundation for theory building, whose perspective does provide insights into the teacher-learner's skill learning ${ }^{[7]}$. However, Roberts claims that the use of teaching practice models does not necessarily lead us to the view that teachers can only learn by imitation. The observation activity shall be adapted in order to achieve personal, contextual and conceptual dimensions of teachers' skill acquisition, by utilizing the following strategies: the use of diversified, realistic exemplars instead of one single idealized model, observation of real teaching practice instead of 'laboratory' conditions, and sufficient opportunities to experiment as well as selfevaluate ${ }^{[7]}$. Therefore, the majority of the LTE sessions offer trainee teachers a channel to have a look at different teaching styles from different senior teachers, under a genuine classroom teaching circumstance, so that these teacher-learners are able to ponder their own image of being a teacher and build personal theories from 'what kind of teacher I am' to 'what kind of teacher I prefer to be'. Furthermore, two chances to practice by themselves, followed by feedback from other trainee and senior teachers, are given, after the selected video observation.

\subsubsection{Allow language teachers to express their thoughts}

Between language teachers' practice and their cognition, "there is a strong relationship" [1]. That is to say, 
their action and thought in language teaching always keep mutually informing. As Borg mentions, teacher educators can hardly understand the teacher-learners and their practice properly without understanding their knowledge, thoughts and beliefs that affect their behaviors. Consequently, extensive study into teacher cognition has been stretched over three decades, indicating that the focus of teacher education shall be shifted away from deciding what trainee teachers need to know and in which way they could be best trained, to trying to understand what trainee teachers actually know and how their knowledge is acquired (Wideen, et al., 1998). The three-hour Narrative and Discussion activity (see Appendix 1 Session 3) offers trainee teachers a platform to narrate their puzzles encountered in teaching practice under the lead of program trainer, including the issue like influences of their prior knowledge on present teaching practice. It not only helps the trainee trainees to know each other better, but also renders the teacher educator familiar with the teacher-learners' unobservable thoughts, laying the foundation for a more constructive and particular evaluation towards each one's teaching practice in the next session.

Regarding the teachers themselves, no matter what level of experience they have, they bring personal theories and prior knowledge to new information ${ }^{[7]}$. Nevertheless, they are usually unaware of this (Eraut, 1994; Argyris and Schon, 1974), so that their personalization of new knowledge could be enriched through self-awareness enhancement, by means of conducting dialogue about teaching incidents with peers and supervisors (e.g., Bailey, 1996; Newell, 1996). In the LTE program, time is permitted for discussion after teacher-learners observing senior teachers' practice in classroom, through video recording. Hence, they can express their own thoughts towards the practice models with their peers, rather than absorbing new information blindly, among which some even doesn't coordinate their personal theories and teaching style. As Roberts ${ }^{[7]}$ notes, uncovering of one's personal theories is an indispensable complement for one to be presented new knowledge, so that they can start from where they already are, and become aware of the differences between new information and their current ideas and practice.

\subsubsection{Encourage teachers to carry out effective self-reflection}

Being reflective promotes teachers' long-term professional development, which grants them better and independent decision-making in teaching ${ }^{[2]}$. To Dewey, reflection is conducive to personal growth in that it guides people to judge a situation from a different point of view, while a single view would restrict the way in which we define problems as well as the resulting solutions. Dewey (1910) also argues that reflective thinking takes place every time our normal activity has been interrupted by surprise or perplexity. As for trainee teachers, it is quite common for their prior teaching knowledge being challenged during their teaching practice, due to the factors like highly diversified learner's needs, increasing expectation on their professionalism and different teaching guidance from other experienced senior teachers. Therefore, being reflective shall become one of their routines in daily life. However, few teachers can deal with this if no spare time and enough support are afforded, especially under the condition that these busy trainee teachers in private institute have no idea about the tactics of how to do and what to do when self-reflecting.

Dewey has put forward a sequence of reflective thinking (i.e., problem constructing--identifying alternative solutions--choosing from options), which still has profound impact on LTE program designing nowadays. His notion has been latter developed by Schon $(1983,1987)$, who makes a distinction between 'reflection-in-action' and 'reflection-on-action'. To be specific, reflection-on-action means teachers reflect on their teaching performance after the event, just like the Self-reflection and Modification activity (see Appendix 1 Session 1\&2) held in the afternoon, which grants the trainee teachers an opportunity to reflect on their teaching practice in the morning. On the other side, reflection-in-action stands for the reflective thinking occurs during teaching, being simultaneous with the action. That is the meaning for teacher educator of this LTE program requiring the trainee teachers to keep a reflective journal, in which they shall write down at least one issue which puzzles them in daily teaching practice, as their assignment 'finished' 
in advance of the next Narrative and Discussion activity (see Appendix 1 Session 3). These issues being written down will be further discussed by teachers altogether in the LTE program and possible solutions are drawn upon after the discussion, for other trainee teachers' future reference in their teaching. This reflection sequence also accords with the one described in Burton ${ }^{[2]}$ : "Noticing a concern; Clarification or expression of the concern in some form; Response to the concern; Processing the response as a whole; Acting on the insights gained."

\subsubsection{Overcome isolated teacher development with collaborative endeavors}

In the past, teaching has always been an occupation being pursued in isolation from colleagues. Nowadays, however, collaborative teacher development has become increasingly common in a broad range of teaching contexts. A crucial element in language teacher development has been to supersede its isolation by collaborative endeavors among teachers, and its practical effects are impressive ${ }^{[11]}$. As Edge (1992) suggests, teachers are likely to understand their own thoughts and experiences better by cooperating with others. Additionally, the power of teachers' collaboration in strengthening their professional development as well as increasing professional dignity has been proposed by Sockett (1993).

According to Johnston ${ }^{[11]}$. there are four major possibilities to conduct collaboration in teacher education program, among which, the most typical option is included in this LTE program: collaborating with fellow teachers, maintaining "the most balanced relationship in terms of power." Although the formats and approaches are not restricted in collaborative teacher development, one fundamental form goes to the teacher study groups, featured by organized and focused interaction among teachers. For instance, in the activities of Observation and Narrative (see Appendix 1), discussion among teacher-learners is encouraged not only after learning from seniors' teaching practice, in order to better understand their own personal theories towards teaching, but also after hearing from peers' narrative of their problems, for the purpose of increasing their professional dignity and learning in a communal way during the exchange of each other's idea for problem-solving solution.

\subsubsection{Help trainee teachers understand more about the context they work in}

A school or institute is a complex social system which perpetuates itself through working relationships and role expectations (Roberts, 1998). In Roberts' (1998) view, the types of language teacher knowledge include contextual knowledge of the school despite knowledge like content, curriculum and pedagogy. Hence, it is important to make the LTE program relevant and sensitive to its institutional beliefs ${ }^{[3,13]}$, on which all the designed activities mentioned before are grounded. To be more specific, partnership with institute (i.e. teaching context) is essential in providing teachers with opportunities to observe and practice teaching as well as to learn from these experiences (Graves, 2009). In addition, the physical and institutional settings in which teacher-learners work often constrain the way they can behave ${ }^{[1]}$, exerting long-term influence on their beliefs, on the way they self-reflect in order to be professional, and on how they could collaborate with their colleagues. This is the motivation for including lecture topics concerning the institute context, plus the guidance for trainee teachers about how to be an active agency in such context (see Appendix 2 Lecture Topic).

\section{Conclusion}

In sum, this LTE program attempts to assist trainee teachers working in private English institutes to better adapt to their job and improve their competitiveness in meeting the requirements of the private institute. Admittedly, a course like this may not foster all teachers to become professionals, but to be a reflective practitioner can be a reachable goal. As Johnson ${ }^{[12]}$, claims, accumulation of professional expertise is based on teachers' capability of understanding how to reflect on teaching. 


\section{Appendix 1}

\begin{tabular}{|c|c|c|c|}
\hline Session 1 & Timetable & & $\begin{array}{l}\text { Subject: Reading and writing } \\
\text { Reading theme: Reading for gist (changing in each session) } \\
\text { Writing theme: Introduction paragraph (changing) }\end{array}$ \\
\hline \multirow{5}{*}{$\begin{array}{l}\text { Morning } \\
\text { session } \\
\text { (3 hours) }\end{array}$} & 9:00-9:15 & $\begin{array}{c}\text { Reading } \\
\text { observation } \\
(10 \mathrm{~min}) \text { and } \\
\text { discussion }(5 \mathrm{~min})\end{array}$ & $\begin{array}{l}\text { Trainee teachers observe a video of one senior reading teacher teaching in } \\
\text { classroom, as a demo class based on this session's reading theme, and note down } \\
\text { what they've learnt from the demo. After watching, discuss in groups of three } \\
\text { about what impresses them and what they think is outdated or too traditional. }\end{array}$ \\
\hline & $9: 15-10: 25$ & $\begin{array}{l}\text { Reading practice } \\
\text { (50min) and } \\
\text { evaluation } \\
\text { (20min) }\end{array}$ & $\begin{array}{l}\text { Each trainee teacher in reading gives their own demo class for } 10 \mathrm{~min} \text {, focusing } \\
\text { on the same reading theme, each followed by a } 4 \text {-min-evaluation from other } \\
\text { trainee and senior teachers. }\end{array}$ \\
\hline & $10: 25-10: 35$ & Tea break & \\
\hline & $10: 35-10: 50$ & \begin{tabular}{|c|} 
Writing \\
observation \\
$(10 \mathrm{~min})$ and \\
discussion $(5 \mathrm{~min})$
\end{tabular} & $\begin{array}{l}\text { Trainee teachers observe a video of one senior writing teacher teaching in } \\
\text { classroom, as a demo class based on this session's writing theme, and note down } \\
\text { what they've learnt from the demo. After watching, discuss in groups of three } \\
\text { about what impresses them and what they think is outdated or too traditional. }\end{array}$ \\
\hline & $10: 50-12: 00$ & $\begin{array}{l}\text { Writing practice } \\
\begin{array}{l}(50 \mathrm{~min}) \text { and } \\
\text { evaluation } \\
(20 \mathrm{~min})\end{array}\end{array}$ & $\begin{array}{l}\text { Each trainee teacher in writing gives their own demo class for } 10 \mathrm{~min} \text {, focusing } \\
\text { on the same writing theme, each followed by a } 4 \text {-min-evaluation from other } \\
\text { trainee and senior teachers. }\end{array}$ \\
\hline $\begin{array}{l}\text { Lunch } \\
\text { time }\end{array}$ & $12: 00-14: 00$ & & \\
\hline \multirow{5}{*}{$\begin{array}{l}\text { Afternoon } \\
\text { session } \\
\text { (3 hours) }\end{array}$} & 14:00-15:00 & $\begin{array}{l}\text { Self-reflection and } \\
\text { modification (1 } \\
\text { hour) }\end{array}$ & $\begin{array}{l}\text { Trainee teachers review the comments given by others on their first practice in } \\
\text { the morning session, and self-reflect on their teaching performance as well as } \\
\text { the content in their teaching material (i.e. PowerPoint slides). Then modify what } \\
\text { needs to be altered and try to adjust their teaching behavior. At the same time, } \\
\text { free discussion or exchange with the senior teachers of relevant subject is } \\
\text { allowed for the trainee teachers' reference. }\end{array}$ \\
\hline & $15: 00-15: 50$ & $\begin{array}{l}\text { Second reading } \\
\text { practice }(50 \mathrm{~min})\end{array}$ & $\begin{array}{l}\text { Trainee reading teachers give their second demo class based on the same theme } \\
\text { in the morning. }\end{array}$ \\
\hline & 15:50-16:00 & General evaluation & Trainer gives comments on everyone's performance and progress. \\
\hline & $16: 00-16: 50$ & $\begin{array}{l}\text { Second writing } \\
\text { practice }(50 \mathrm{~min})\end{array}$ & $\begin{array}{l}\text { Trainee writing teachers give their second demo class based on the same theme } \\
\text { in the morning. }\end{array}$ \\
\hline & $16: 50-17: 00$ & General evaluation & Trainer gives comments on everyone's performance and progress. \\
\hline
\end{tabular}




\begin{tabular}{|c|c|c|c|}
\hline Session 2 & Timetable & & $\begin{array}{l}\text { Subject: Listening and speaking } \\
\text { Listening theme: Listening for gist (changing in each session) } \\
\text { Speaking theme: Focus on places description (changing) } \\
\end{array}$ \\
\hline \multirow{5}{*}{$\begin{array}{l}\text { Morning } \\
\text { session } \\
\text { (3 hours) }\end{array}$} & $9: 00-9: 15$ & $\begin{array}{l}\text { Listening } \\
\text { observation } \\
(10 \mathrm{~min}) \text { and } \\
\text { discussion (5min) }\end{array}$ & $\begin{array}{l}\text { Trainee teachers observe a video of one senior listening teacher teaching in } \\
\text { classroom, as a demo class based on this session's listening theme, and note } \\
\text { down what they've learnt from the demo. After watching, discuss in groups of } \\
\text { three about what impresses them and what they think is outdated or too } \\
\text { traditional. }\end{array}$ \\
\hline & $9: 15-10: 25$ & $\begin{array}{l}\text { Listening practice } \\
\text { (50min) and } \\
\text { evaluation } \\
\text { (20min) }\end{array}$ & $\begin{array}{l}\text { Each trainee teacher in listening gives their own demo class for } 10 \mathrm{~min} \text {, focusing } \\
\text { on the same listening theme, each followed by a } 4 \text { min evaluation from other } \\
\text { trainee and senior teachers. }\end{array}$ \\
\hline & 10:25-10:35 & Tea break & \\
\hline & 10:35-10:50 & $\begin{array}{c}\text { Speaking } \\
\text { observation } \\
(10 \mathrm{~min}) \text { and } \\
\text { discussion (5min) }\end{array}$ & $\begin{array}{l}\text { Trainee teachers observe a video of one senior speaking teacher teaching in } \\
\text { classroom, as a demo class based on this session's speaking theme, and note } \\
\text { down what they've learnt from the demo. After watching, discuss in groups of } \\
\text { three about what impresses them and what they think is outdated or too } \\
\text { traditional. }\end{array}$ \\
\hline & 10:50-12:00 & $\begin{array}{l}\text { Speaking practice } \\
\text { (50min) and } \\
\text { evaluation } \\
\text { (20min) }\end{array}$ & $\begin{array}{l}\text { Each trainee teacher in speaking gives their own demo class for } 10 \mathrm{~min} \text {, focusing } \\
\text { on the same speaking theme, each followed by a 4-min-evaluation from other } \\
\text { trainee and senior teachers. }\end{array}$ \\
\hline Lunch time & 12:00-14:00 & & \\
\hline \multirow{5}{*}{$\begin{array}{l}\text { Afternoon } \\
\text { session } \\
(3 \text { hours })\end{array}$} & 14:00-15:00 & $\begin{array}{l}\text { Self-reflection and } \\
\text { modification } \\
\quad(1 \text { hour })\end{array}$ & $\begin{array}{l}\text { Trainee teachers review the comments given by others on their first practice in } \\
\text { the morning session, and self-reflect on their teaching performance as well as } \\
\text { the content in their teaching material (i.e., PowerPoint slides). Then modify what } \\
\text { needs to be altered and try to adjust their teaching behavior. At the same time, } \\
\text { free discussion or exchange with the senior teachers of relevant subject is } \\
\text { allowed for the trainee teachers' reference. }\end{array}$ \\
\hline & $15: 00-15: 50$ & $\begin{array}{l}\text { Second listening } \\
\text { practice }(50 \mathrm{~min})\end{array}$ & $\begin{array}{l}\text { Trainee listening teachers give their second demo class based on the same theme } \\
\text { in the morning. }\end{array}$ \\
\hline & 15:50-16:00 & $\begin{array}{c}\text { General } \\
\text { evaluation }\end{array}$ & $\begin{array}{l}\text { Trainer gives comments on everyone's performance and } \\
\text { progress. }\end{array}$ \\
\hline & $16: 00-16: 50$ & $\begin{array}{l}\text { Second speaking } \\
\text { practice }(50 \mathrm{~min})\end{array}$ & $\begin{array}{l}\text { Trainee speaking teachers give their second demo class } \\
\text { based on the same theme in the morning. }\end{array}$ \\
\hline & $16: 50-17: 00$ & $\begin{array}{c}\text { General } \\
\text { evaluation }\end{array}$ & $\begin{array}{l}\text { Trainer gives comments on everyone's performance and } \\
\text { progress. }\end{array}$ \\
\hline
\end{tabular}




\begin{tabular}{|c|c|c|c|}
\hline Session 3 & Timetable & & $\begin{array}{l}\text { Lecture and narrative } \\
\text { Lecture: Practical skills narrative: Problem-solving }\end{array}$ \\
\hline \multirow{3}{*}{$\begin{array}{l}\text { Morning } \\
\text { session } \\
\text { (3 hours) }\end{array}$} & 9:00-10:25 & 1st lecture & Theme: Powerpoint Format and Adjustment \\
\hline & $10: 25-10: 35$ & Tea break & \\
\hline & $10: 35-12: 00$ & 2nd lecture & Theme: How to leave a best impression on your students in the first class? \\
\hline Lunch time & 12:00-14:00 & & \\
\hline $\begin{array}{l}\text { Afternoon } \\
\text { session } \\
\text { (3 hours) }\end{array}$ & $14: 00-17: 00$ & $\begin{array}{l}\text { Narrative and } \\
\text { discussion }\end{array}$ & $\begin{array}{l}\text { In turns, each trainee teacher narrates the problem that has puzzled them during } \\
\text { their daily work, followed by a discussion in groups about its solution. After } \\
\text { discussion, the trainer synthesizes each group's solution to the problem, and } \\
\text { gives applicable solutions for trainee teachers' future reference according to } \\
\text { their own situation. }\end{array}$ \\
\hline
\end{tabular}

\section{Appendix 2}

\begin{tabular}{|c|c|c|c|}
\hline Session & Timetable & & Lecture Topic \\
\hline \multirow{2}{*}{ Session 3} & $9: 00-10: 25$ & 1st lecture & Powerpoint Format and Effective Adjustment \\
\hline & $10: 35-12: 00$ & 2nd Lecture & To Leave a Best Impression on Students in the First Class \\
\hline \multirow{2}{*}{ Session 6} & $9: 00-10: 25$ & 3rd lecture & The School Operation and Its Demands on Teachers \\
\hline & $10: 35-12: 00$ & 4th lecture & To Be an Active Agency \\
\hline \multirow{2}{*}{ Session 9} & 9:00-10:25 & 5th lecture & To Better Exchange and Communicate with Colleagues \\
\hline & $10: 35-12: 00$ & 6th lecture & To Formulate Your Own Teaching Style \\
\hline \multirow{2}{*}{ Session 12} & 9:00-10:25 & 7th lecture & Classroom Discourse 1: Managerial (Part1) \\
\hline & $10: 35-12: 00$ & 8th lecture & Classroom Discourse 1: Managerial (Part2) \\
\hline \multirow{2}{*}{ Session 15} & 9:00-10:25 & 9th lecture & Classroom Discourse 2: Materials (Part1) \\
\hline & $10: 35-12: 00$ & 10th lecture & Classroom Discourse 2: Materials (Part2) \\
\hline \multirow{2}{*}{ Session 18} & $9: 00-10: 25$ & 11th lecture & Classroom Discourse 3: Skills and Systems (Part1) \\
\hline & $10: 35-12: 00$ & 12th lecture & Classroom Discourse 3: Skills and Systems (Part2) \\
\hline \multirow{2}{*}{ Session 21} & $9: 00-10: 25$ & 13th lecture & Classroom Discourse 4: Classroom Context (Part1) \\
\hline & $10: 35-12: 00$ & 14th lecture & Classroom Discourse 4: Classroom Context (Part2) \\
\hline \multirow{2}{*}{ Session 24} & 9:00-10:25 & 15th lecture & To Be a Reflective Practioner \\
\hline & $10: 35-12: 00$ & 16th lecture & To Get Abundant Teaching Resources \\
\hline
\end{tabular}

\section{Disclosure statement}

The author declares that there is no conflict of interest. 


\section{References}

[1] Borg S, 2009, Language Teacher Cognition. In Burns, A. and Richards, J. C. (Eds) The Cambridge Guide to Second Language Teacher Education. Cambridge: Cambridge University Press.

[2] Burton J, 2009, Reflective Practice. In Burns, A. and Richards, J. C. (Eds) The Cambridge Guide to Second Language Teacher Education. Cambridge: Cambridge University Press.

[3] Canagarajah AS, 1999, Resisting Linguistic Imperialism in English Teaching. Oxford: Oxford University Press.

[4] Darling-Hammond L, Lieberman A, 2012, Teacher Education Around the World: Changing Policies and Practices. London: Routledge.

[5] Freeman D, Johnson KE, 1998, Reconceptualizing the Knowledge-base of Language Teacher Education. TESOL Quarterly, 32 (3), 397-417.

[6] Gray J, Block D, 2012, The Marketization of Language Teacher Education and Neoliberalism: Characteristics, Consequences and Future Prospects. In Block, D., Gray J and Holborow M, (Eds) Neoliberalism and Applied Linguistics. London: Routledge.

[7] Graves K, 2009, The Curriculum of Second Language Teacher Education. In Burns A, and Richards JC, (Eds) The Cambridge Guide to Second Language Teacher Education. Cambridge: Cambridge University Press.

[8] Hayes D, 2005, Exploring the Lives of Non-native Speaking English Educators in Sri Lanka. Teachers and Teaching: Theory and Practice, 11 (2), 169-94.

[9] Johnson KE, 1994, The Emerging Beliefs and Instructional Practices of Pre-service ESL Teachers. Teaching and Teacher Education, 10, 439-52.

[10] Johnson K, 2000, Innovations in TESOL Teacher Education: A Quiet Revolution. In Johnson K, (Ed) Teacher Education: Case Studies in Teacher Practice Series. Alexandria, VI: TESOL.

[11] Johnston B, 2009, Collaborative Teacher Development. In Burns, A. and Richards, J. C. (Eds) The Cambridge Guide to Second Language Teacher Education. Cambridge: Cambridge University Press.

[12] Johnston K, 2014, Forward. In Said, S. B. and Zhang, L. J. (Eds) Language Teachers and Teaching: Global Perspectives, Local Initiatives. New York: Routledge.

[13] Kumaravadivelu B, 2001, Toward a Post-method Pedagogy. TESOL Quarterly, 35 (4), 537-60.

[14] Lee E, Lew L, 2001, Diary Studies: The Voices of Nonnative English Speakers in a Master of Arts Program in Teaching English to Speakers of Other Languages. The CATESOL Journal, 13 (1), 135-49.

[15] Morita N, 2000, Discourse Socialization Through Oral Classroom Activities in a TESL Graduate Program. TESOL Quarterly, 34 (2), 279-310. 